\title{
AN ANALYSIS OF PREDISPOSING, ENABLING, AND REINFORCING FACTORS IN PREVENTING THE TRANSMISSION OF PULMONARY TUBERCULOSIS DISEASE ON PATIENTS' RELATIVES IN TULUNGAGUNG REGENCY
}

\author{
Chalies Diah Pratiwi ${ }^{1}$, Sandu Siyoto ${ }^{2}$, Indasah ${ }^{3}$ \\ Department of Postgraduate of Kesmas STIKes Surya Mitra Husada Kediri \\ Email : diahchalies@gmail.com
}

\begin{abstract}
Tuberculosis (TB) is one of the major causes of death. In the report of Tuberculosis Global 2014 which was realeased by World Health Organization (WHO) stated that the incidence happened in Indonesia was 1 million new cases every year. The percentage of the cases in Indonesia is 10 percent from entire cases in the world, so as to be the most second cases country along with Tiongkok. The objective of this study is to know the effect of predisposing, enabling, and reinforcing factors towards the efforts in preventing the transmission of pulmonary $T B$ diseases on patients' relatives in Tulungagung regency.This study was non experimental quantitative research by using research design with Cross Sectional observation method. The samples this study were the relatives who have the most emotional closeness with the patient of pulmonary TB as much as 285 respondents. The data obtained through questionnaire then it was analyzed by using ordinal regression test. Based on the ordinal regression test which was conducted where $\rho<0,05$, hence that there was the effect of gender on the prevention of pulmonary TB transmission in Tulungagung regency, the effect of educational level on the prevention of pulmonary $T B$ transmission in Tulungagung regency, the effect of knowledge on the prevention of Pulmonary TB transmission in Tulungagung regency, the effect of dwelling density on the prevention of pulmonary TB transmission in Tulungagung regency and the effect of coaching officer on the prevention of Pulmonary $T B$ transmission in Tulungagung regency. Improvement of guidance and quality of service in Pulmonary TB prevention program by involving the family is expected so the patient will do prevention effort to pulmonary tuberculosis disease to support local goverment effort in decreasing incidence of pulmonary $T B$ generally and particularly maintain personal health to achieve health society which play an active role in national development.
\end{abstract}

Keyword: Predisposing, Enabling, Reinforsing Factors, Pulmonary TB Prevention. 


\section{INTRODUCTION}

Tuberculosis (TB) is one of the major causes of death where the infection mostly occurred to people between 15 and 54 years old which belong to the most productive age. this case can cause the increasing of social burden and financial for the keluarga pasien It causes the increasing of social and financial load for patients' relatives. From the newest survey result, the number of new cases of tuberculosis or TB in Indonesia is estimated to reach 1 million every year or increase twofold from the previous estimation. The position of Indonesia rise as the most second TB cases country after India (Kompas, 2016).

District Health Office (DHO) of East Java recorded the number of Pulmonary Tuberculosis (TB) positive Acid Fast Staining (BTA) reached 15.371 cases. "The community should be aware because Pulmonary TB positive Acid Fast Staining transmitted quickly," states by the Chief of DHO East Java, dr Harsono in Surabaya, on Friday $(22 / 1)$. The Chief of DHO East Java,dr Harsono reveals, many cases about Pulmonary TB positive Acid Fast Staining can accelerate the rising of the new case of TB in East Java. By handling and preventing correctly, it is expected that TB cases in East Java does not increase. Until now, TB cases in East Java reach as much as 40.000 people, while patients who have been succeed to be treated as much as 28.000 . (Surabayaonline, 2016).

Based on the data from Tulungagung regency District Health Office the number of Pulmonary TB in Tulungagung regency on 2016 was made up 983 people.
Based on the introduction survey which was conducted in Puskesmas, and based on the officer of Puskesmas, the activity of preventing Pulmonary TB disease was already conducted by helding a conceling of sanitation enviromental health clinic, immunization, and visiting the house in order to accomplish the enviromental coaching which caused pulmonary TB. The behaviour of Pulmonary TB patients who are still throw their saliva carelessly and it indicated the factor of pulmonary TB transmission. The reluctance of society to check their health indicated the caused of increasing pulmonary $\mathrm{TB}$ in Tulungagung regency.

Education to the community about the preventing of Pulmonary TB is important and if the people are already infected by pulmonary TB, the patient can be recovered if they consume the medicine regularly. Due to the lack of information, alot of pulmonary TB patients in the early step do not know the important of using mask in order to prevent the transmission disease. Lack of information also make patients have a risk to stop consuming the medicine after they feel normal. An other non-medical factors are family's support and community towards pulmonary TB patient. Medicinal treatment for months, even 2 years if the microbe is already resistance, can make patient feels bored and gets depression. (Kompas, 2016).

From the statements above, the researcher interested to analyse predisposing, enabling, and reinforcing factors in preventing the transmission of Pulmonary TB disease on the patients' relatives in Tulungagung regency. 


\section{METHOD}

This research was non experimental quantitative research by using obsevational research design with Cross Sectional observation method, is a research for learning the dynamics correlation between risk factors with effect, by using observation approach or poin time approach. Means that each subject of research was only observed one times and the measurement was conducted on the character status or subject variabel at the time of examination. The objective of this study is to observe the correlation between risk factors with the effect in the form of disease or the certain condition at the same time. (Siyoto, 2015)

This research was conducted in Tulungagung regency, on 4th August 2017 until 4th September 2017. Sample of this research was as much as 285 family members which have a close relation with patients' relatives of pulmonary $\mathrm{TB}$ in Tulungagung regency. Sampling used was probability sampling with multistage sampling technique, is a sampling technique which is done based on the level of region gradually. The implementation is by dividing the region of population into sub-region and each of subregion is divided into the part which is smaller. (Notoadmojo, 2011)

The instrument of data collection which was used in the form of questionnaire which contained data about predisposing factors (age, gender, education, occupation, and knowledge), enabling factors (dwelling density, ventilation are, widow area, and house distance to health facilities) and reinforcing factors (relatives role as PMO, coaching health officer), in preventing the transmission of pulmonary TB).

Analysis method which was used was ordinal regression on $\alpha=0,05$ as the purpose to know predisposing factors (age, gender, education, and knowledge), enabling factors (dwelling density, ventilation area, window area, and house distance to health facilities), and reinforcing factors (active role as PMO, coaching health officer), in preventing the transmission of pulmonary Tuberculosis in Tulungagung regency.

\section{RESEARCH RESULT}

Based on the research result which was conducted in Tulungagung Regency from August up to September 2017 as much as 285 corespondents, then the results were as follows:

\section{THE CHARACTERISTICS OF RESPONDENTS \\ Table 1: The Characteristics of Predisposing Factors on \\ Respondents}

\begin{tabular}{lcc}
\hline Predisposing factors & $\mathrm{N}$ & $\mathrm{f}(\%)$ \\
\hline Gender & & \\
Man & 133 & 46,6 \\
Woman & 152 & 53,4 \\
Age & & \\
$12-17$ y.o & 1 & 0,3 \\
$18-25$ y.o & 26 & 9,1 \\
26-35 y.o & 55 & 19,3 \\
36-45 y.o & 99 & 34,1 \\
46-55 y.o & 77 & 27,1 \\
56-65 y.o & 20 & 7 \\
$\geq 65$ y.o & 7 & 2,4 \\
Educational Level & & \\
Elementary School & 44 & 15,4 \\
Junior High School & 88 & 30,8 \\
Senior High School & 125 & 43,8 \\
Academy/Universities & 28 & 10 \\
Job Field & & \\
Housewife & 102 & 36,1 \\
Farmer & 42 & 14,5 \\
Laborer & 29 & 10,3 \\
Seller & 31 & 10,7 \\
Private employees & 75 & 26,2 \\
Civil servants & 3 & 1,1 \\
\end{tabular}




\begin{tabular}{lcc} 
Students & 3 & 1,1 \\
Knowledge & & \\
Less & 40 & 14 \\
Satisfactory & 45 & 15,7 \\
Good & 200 & 70,3 \\
\hline
\end{tabular}

Based on the table above, the greatest number of respondents was women as much as $53,4 \%$, aged between 35-45 years old as much as $34,1 \%$, having a knowledge as Senior High School as much as 125, housewife as much as $36,1 \%$, and having a good knowlede about pulmonary TB made up $70,3 \%$.

Table 2: The Characteristics of Enabling Factors on Respondent

\begin{tabular}{|c|c|c|}
\hline Dwelling Density & $\mathrm{N}$ & $\mathrm{F}(\%)$ \\
\hline$<2,5 \times 3 \mathrm{~m} /$ person & 116 & 40,7 \\
\hline$\geq 2,5 \times 3 \mathrm{~m} /$ person & 169 & 59,3 \\
\hline Ventilation Area & & \\
\hline $\begin{array}{l}<10 \% \text { from the wide of } \\
\text { floor }\end{array}$ & 166 & 58,3 \\
\hline $\begin{array}{l}\geq 10 \% \text { from the wide of } \\
\text { floor }\end{array}$ & 119 & 41,7 \\
\hline Window Area & & \\
\hline $\begin{array}{l}<15 \%-20 \% \text { from the wide } \\
\text { of floor }\end{array}$ & 169 & 59,3 \\
\hline $\begin{array}{l}\geq 15 \%-20 \% \text { from the } \\
\text { wide of floor }\end{array}$ & 116 & 40,7 \\
\hline $\begin{array}{l}\text { House distance to health } \\
\text { facilities }\end{array}$ & & \\
\hline$<3 \mathrm{Km}$ & 167 & 48,6 \\
\hline$\geq 3 \mathrm{Km}$ & 118 & 41,4 \\
\hline
\end{tabular}

Based on the table above, the greatest numbers of respondents which have dwelling density $\geq 2,5 \mathrm{x}$ $3 \mathrm{~m} /$ person $59,3 \%$, ventilation $<10 \%$ from wide of floor $58,3 \%$, window < $15 \%-20 \%$ from wide of floor $59,3 \%$ and house distance to health facilities

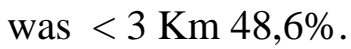

Table 3: The characteristics of Reinforcing Factors on Respondents

\begin{tabular}{lcc}
\hline Active role as PMO & N & f (\%) \\
\hline Less & 73 & 25,6 \\
Satisfactory & 72 & 25,2 \\
Good & 140 & 49,2 \\
& & \\
Coaching of Health & & \\
Officer & & \\
Less & 64 & 22,4 \\
Satisfactory & 138 & 48,4 \\
Good & 83 & 29,2
\end{tabular}

Based on the table above, the greatest number of respondents which have a good active role as PMO as much as 49,2\% and respondents who get satisfactory coaching from health officer as much as $48,4 \%$.

\section{BIVARIATE ANALYSIS}

The effect of gender in preventing the transmission of pulmonary $\mathrm{TB}$

From analysis results, it was obtained $\rho=0,009$ where $\rho<\alpha(0,05)$ so $\mathrm{H} 0$ was refused which meant that there was an influence between gender respondents with the preventing of Pulmonary TB transmission in Tulungagung regency.

Based on the research results, it was obtained that majority respondents was men as much as 92 respondents $(32,3 \%)$ in which their behaviour was less in preventing pulmonary TB. 
Table 1 : The Effect of Gender in preventing the transmission of Pulmonary TB disease

\begin{tabular}{|c|c|c|c|c|c|c|c|}
\hline \multirow[t]{3}{*}{ Gender } & \multicolumn{6}{|c|}{$\begin{array}{c}\text { Prevention of Pulmonary TB behavior towards } \\
\text { the relatives }\end{array}$} & \multirow[t]{3}{*}{$\rho$ value } \\
\hline & \multicolumn{2}{|c|}{ Less } & \multicolumn{2}{|c|}{ Satisfactory } & \multicolumn{2}{|c|}{ Good } & \\
\hline & $\mathrm{N}$ & $\mathrm{F}$ & $\mathrm{N}$ & $\mathrm{F}$ & $\mathrm{N}$ & $\mathrm{F}$ & \\
\hline Man & 92 & 32,3 & 22 & 7,7 & 19 & 6,7 & 0,009 \\
\hline Women & 79 & 27,7 & 45 & 15,8 & 28 & 9,8 & \\
\hline
\end{tabular}

The effect of Respondents' ages in preventing Pulmonary TB Transmission

From the analysis result, it was obtained $\rho=0,000$ which $\rho<\alpha$
$(0,05)$ so as to $\mathrm{H} 0$ was rejected which meant there was an effect between respondents' ages with the prevention of Pulmonary TB in Tulungagung Regency.

Table 2: The effect of age in preventing the transmission of Pulmonary TB

\begin{tabular}{|c|c|c|c|c|c|c|c|}
\hline \multirow[t]{3}{*}{ Age } & \multicolumn{6}{|c|}{$\begin{array}{l}\text { Pulmonary TB disease prevention behavior } \\
\text { towards the relatives }\end{array}$} & \multirow[t]{3}{*}{$\rho$ value } \\
\hline & \multicolumn{2}{|c|}{ Less } & \multicolumn{2}{|c|}{ Satisfactory } & \multicolumn{2}{|c|}{ Good } & \\
\hline & $\mathrm{N}$ & $\mathrm{F}$ & $\mathrm{N}$ & $\mathrm{F}$ & $\mathrm{N}$ & $\mathrm{F}$ & \\
\hline $12-17$ y.o & 1 & 0,4 & 0 & 0 & 0 & 0 & \\
\hline $18-25$ y.o & 9 & 3,2 & 6 & 2,1 & 11 & 3,9 & \\
\hline $26-35$ y.o & 22 & 7,7 & 15 & 5,3 & 18 & 6,3 & $\rho=0,000$ \\
\hline $36-45$ у.о & 62 & 21,8 & 24 & 8,4 & 11 & 3,9 & \\
\hline $46-55$ y.o & 55 & 19,3 & 16 & 5,6 & 6 & 2,1 & \\
\hline $56-65$ y.o & 17 & 6,0 & 2 & 0,7 & 1 & 0,4 & \\
\hline$>65$ y.o & 5 & 1,8 & 4 & 1,4 & 0 & $\mathbf{0}$ & \\
\hline
\end{tabular}

The Effect of Respondents' Education Level in Preventing Pulmonary TB Transmission

From the test result, it was gained $\rho=0,000$ where $\rho<\alpha(0,05)$ so as to H0 was rejected which meant there was an effect between respondents' education level with the prevention of Pulmonary TB transmission in Tulungagung Regency.

Table 3 : The effect of education level in preventing the transmission of Pulmonary TB disease

\begin{tabular}{|c|c|c|c|c|c|c|c|}
\hline \multirow[t]{3}{*}{ Education Level } & \multicolumn{6}{|c|}{$\begin{array}{c}\text { Pulmonary TB disease prevention behavior } \\
\text { towards the relatives }\end{array}$} & \multirow[t]{3}{*}{$\rho$ value } \\
\hline & \multicolumn{2}{|c|}{ Less } & \multicolumn{2}{|c|}{ Satisfactory } & \multicolumn{2}{|c|}{ Good } & \\
\hline & $\mathrm{N}$ & $\mathrm{F}$ & $\mathrm{N}$ & $\mathrm{F}$ & $\mathrm{N}$ & $\mathrm{F}$ & \\
\hline Elementary School & 34 & 11,9 & 8 & 2,8 & 2 & $\mathbf{0 , 7}$ & \\
\hline Junior High School & 52 & 18,2 & 25 & 8,8 & 11 & 3,9 & $\rho=0,000$ \\
\hline Senior High School & 81 & 28,4 & 29 & 10,2 & 14 & 4,9 & \\
\hline University & 4 & 1,4 & 5 & 1,8 & 20 & 7,0 & \\
\hline
\end{tabular}


4. The Effect of Respondents' Job Field in preventing Pulmonary TB Transmission

From the test result, it was gained $\rho=0,000$ where $\rho<\alpha(0,05)$ so as to $\mathrm{H} 0$ was rejected which meant there was an effect between respondents job field and the prevention of Pulmonary TB transmission in Tulungagung Regency.

Table 4 : The effect of job field in preventing the transmission of pulmonary TB

\begin{tabular}{|c|c|c|c|c|c|c|c|}
\hline \multirow[t]{3}{*}{ Kind of work } & \multicolumn{6}{|c|}{$\begin{array}{l}\text { Pulmonary TB disease prevention behavior towards } \\
\text { the relatives }\end{array}$} & \multirow[t]{3}{*}{$\rho$ value } \\
\hline & \multirow[t]{2}{*}{ Less } & \multicolumn{3}{|c|}{ Sutisfactory } & \multicolumn{2}{|c|}{ Good } & \\
\hline & & $\mathrm{F}$ & $\mathrm{N}$ & $\mathrm{F}$ & $\mathrm{N}$ & $\mathrm{F}$ & \\
\hline Housewife & 60 & 21,1 & 30 & 10,5 & 13 & 4,6 & \\
\hline Farmer & 28 & 9,8 & 10 & 3,5 & 8 & 2,8 & \\
\hline Laborer & 21 & 7,4 & 1 & $\mathbf{0 , 4}$ & 4 & 1,4 & $\rho=\mathbf{0 , 0 0 0}$ \\
\hline Seller & 13 & 4,6 & 7 & 2.5 & 10 & 3,5 & \\
\hline Private Employees & 46 & 16,1 & 17 & 6,0 & 12 & 4,2 & \\
\hline Civil Servants & $\mathbf{0}$ & $\mathbf{0 , 0}$ & 2 & $\mathbf{0 , 7}$ & 0 & $\mathbf{0 , 0}$ & \\
\hline Students & 3 & 1,1 & 0 & $\mathbf{0 , 0}$ & 0 & 0 & \\
\hline
\end{tabular}

5. The Effect of Respondents' Knowledge in Preventing Pulmonary TB Transmission

From the test result, it was obtained $\rho=0,000$ where $\rho<\alpha$ $(0,05)$ so as to H0 was rejected which meant there was an effect between respondents' knowledge and the prevention of Pulmonary TB transmission in Tulungagung Regency.

Table 5: The effect of knowledge in preventing the transmission of Pulmonary TB

\begin{tabular}{|c|c|c|c|c|c|c|c|}
\hline \multirow[t]{3}{*}{$\begin{array}{l}\text { Respondents' } \\
\text { Knowledge }\end{array}$} & \multicolumn{6}{|c|}{$\begin{array}{l}\text { Pulmonary TB disease prevention behavior towards the } \\
\text { relatives }\end{array}$} & \multirow[t]{2}{*}{$\rho$ value } \\
\hline & \multicolumn{2}{|c|}{ Less } & \multicolumn{2}{|c|}{ Satisfactory } & \multicolumn{2}{|c|}{ Good } & \\
\hline & $\mathrm{N}$ & $\mathrm{F}$ & $\mathrm{N}$ & $\mathrm{F}$ & $\mathrm{N}$ & $\mathrm{F}$ & \\
\hline Less & 23 & 7,4 & 10 & 3,5 & 7 & 2,5 & \\
\hline Satisfactory & 22 & 7,7 & 13 & 4,6 & 10 & 3,5 & $\rho=0,000$ \\
\hline
\end{tabular}

6. The Effect of Dwelling Density in Preventing Pulmonary TB Transmission

From the test result, it was obtained $\rho=0,590$ where $\rho>\alpha$ $(0,05)$ so as to H0 was accepted which meant there was no effect between dwelling density with the prevention of Pulmonary TB transmission in Tulungagung Regency.

Table 6: The effect of dwelling density in preventing the transmission of Pulmonary TB disease 


\begin{tabular}{|c|c|c|c|c|c|c|c|}
\hline \multirow[t]{3}{*}{ Dwelling Density } & \multicolumn{6}{|c|}{$\begin{array}{c}\text { Pulmonary TB disease prevention behavior towards the } \\
\text { relatives }\end{array}$} & \multirow[t]{2}{*}{$\rho$ value } \\
\hline & \multicolumn{2}{|c|}{ Less } & \multicolumn{2}{|c|}{ Satisfactory } & \multicolumn{2}{|r|}{ Good } & \\
\hline & $\mathrm{N}$ & $\mathrm{F}$ & $\mathrm{N}$ & $\mathrm{F}$ & $\mathrm{N}$ & $\mathrm{F}$ & \\
\hline$\geq 2 \times, 5 \mathrm{~m}^{2}$ & 102 & 35,8 & 42 & 14,7 & 25 & 8,8 & $\rho=0,590$ \\
\hline$<2 \times, 5 \mathrm{~m}^{2}$ & 69 & 24,2 & 25 & 8,8 & 22 & 7,7 & \\
\hline
\end{tabular}

7. The effect of Ventilation in Preventing Pulmonary TB Transmission

From the test result was obtained $\rho=0,768$ where $\rho>\alpha$ $(0,05)$ so as to H0 was accepted

which meant there was no effect between ventilation area with the prevention of Pulmonary TB transmission in Tulungagung Regency.

Table 7: The effect of ventilation broad in preventing the transmission of Pulmonary TB disease

\begin{tabular}{lccccccc}
\hline Ventilation & \multicolumn{9}{c}{ Pulmonary TB disease prevention behavior towards } & \multirow{2}{*}{$\rho$ value } \\
& \multicolumn{9}{c}{ the relatives } & \\
& Less & \multicolumn{4}{c}{ Satisfactory } & \multicolumn{3}{c}{ Good } & \\
\hline & $\mathrm{N}$ & $\mathrm{F}$ & $\mathrm{N}$ & $\mathrm{F}$ & $\mathrm{N}$ & $\mathrm{F}$ & \\
\hline$<10 \%$ floor area & $\mathbf{1 0 3}$ & $\mathbf{3 6 , 1}$ & $\mathbf{3 7}$ & $\mathbf{1 3 , 0}$ & $\mathbf{2 7}$ & $\mathbf{9 , 5}$ & $\boldsymbol{\rho}=\mathbf{0 , 7 6 8}$ \\
$\geq 10 \%$ floor area & $\mathbf{6 8}$ & $\mathbf{2 3 , 2}$ & $\mathbf{3 0}$ & $\mathbf{1 0 , 5}$ & $\mathbf{2 0}$ & $\mathbf{7 , 0}$ &
\end{tabular}

8. The Effect of Window Area in Preventing Pulmonary TB transmission

From the test result yielded $\rho=0,123$ where $\rho>\alpha(0,05)$ so as to
H0 was accepted which meant there was no effect between window broad with the prevention of Pulmonary TB transmission in Tulungagung

Regency.

Table 8: The effect of window broad in preventing the transmission of Pulmonary TB disease

\begin{tabular}{|c|c|c|c|c|c|c|c|}
\hline \multirow[t]{3}{*}{ Window } & \multicolumn{6}{|c|}{$\begin{array}{l}\text { Pulmonary TB disease prevention behavior } \\
\text { towards the relatives }\end{array}$} & \multirow[t]{3}{*}{$\rho$ value } \\
\hline & \multicolumn{2}{|c|}{ Less } & \multicolumn{2}{|c|}{ Satisfactory } & \multicolumn{2}{|c|}{ Good } & \\
\hline & $\mathrm{N}$ & $\mathrm{F}$ & $\mathrm{N}$ & $\mathrm{F}$ & $\mathrm{N}$ & $\mathrm{F}$ & \\
\hline$\geq 15 \%-20 \%$ floor area & 62 & 21,8 & 34 & 11,9 & 19 & 6,7 & $\rho=0,123$ \\
\hline$<15 \%-20 \%$ floor area & 109 & 38,2 & 33 & 11,6 & 28 & $\mathbf{9 , 8}$ & \\
\hline
\end{tabular}

9. The Effect of House Distance to Health Facility in Preventing Pulmonary TB Transmission

From the test result, it was obtained $\rho=0,023$ where $\rho<\alpha$

Table 9: The Effect of House Distance to Health Facility with the Prevention of Pulmonary TB Transmission
$(0,05)$ so as to $\mathrm{H} 0$ was rejected which meant there was an effect between house distance and health facility with the prevention of Pulmonary TB transmission in Tulungagung Regency. 


\begin{tabular}{|c|c|c|c|c|c|c|c|c|}
\hline \multirow[t]{3}{*}{$\begin{array}{l}\text { House distance } \\
\text { Health Facility }\end{array}$} & to & \multicolumn{6}{|c|}{$\begin{array}{c}\text { Pulmonary TB disease prevention behavior towards } \\
\text { the relatives }\end{array}$} & \multirow[t]{3}{*}{$\rho$ value } \\
\hline & & \multicolumn{2}{|c|}{ Less } & \multicolumn{2}{|c|}{ Satisfactory } & \multicolumn{2}{|c|}{ Good } & \\
\hline & & $\mathrm{N}$ & $\mathrm{F}$ & $\mathrm{N}$ & $\mathrm{F}$ & $\mathrm{N}$ & $\mathrm{F}$ & \\
\hline$<3 \mathrm{Km}$ & & 89 & 31,2 & 43 & 15,1 & 34 & 11,9 & $\rho=0,023$ \\
\hline$\geq 3 \mathrm{Km}$ & & 82 & 28,8 & 24 & 8,4 & 13 & 4,6 & \\
\hline
\end{tabular}

10 The Effect of PMO in Preventing Pulmonary TB Transmission

From the test result, it yielded $\rho=0,021$ where $\rho<\alpha(0,05)$ so as to H0 was rejected which meant there was an effect between an active role of relative members as PMO with the prevention of Pulmonary TB transmission in Tulungagung Regency

Table 10: The Effect of PMO with the Prevention of Pulmonary TB Transmisiion

\begin{tabular}{|c|c|c|c|c|c|c|c|}
\hline \multirow[t]{3}{*}{$\begin{array}{l}\text { An active role of relative } \\
\text { members as PMO }\end{array}$} & \multicolumn{6}{|c|}{$\begin{array}{l}\text { Pulmonary TB disease prevention behavior } \\
\text { towards the relatives }\end{array}$} & \multirow[t]{3}{*}{$\rho$ value } \\
\hline & \multicolumn{2}{|c|}{ Less } & \multicolumn{2}{|c|}{ Satisfactory } & \multicolumn{2}{|c|}{ Good } & \\
\hline & $\mathrm{N}$ & $\mathrm{F}$ & $\mathrm{N}$ & $\mathrm{F}$ & $\mathrm{N}$ & $\mathrm{F}$ & \\
\hline Less & 52 & 18,2 & 10 & 3,5 & 11 & 3,9 & $\rho=0,021$ \\
\hline Sutisfactory & 48 & 16,8 & 20 & 7,0 & 7 & 2,5 & \\
\hline Good & 71 & 24,7 & 37 & 13,0 & 29 & 10,2 & \\
\hline
\end{tabular}

11. The Effect of Officers Coaching in Preventing Pulmonary TB Transmission

From the Chi square test result, it was obtained $\rho=0,000$ where $\rho<\alpha(0,05)$ so as to $\mathrm{H} 0$ was rejected which meant there was an effect between officers coaching with the prevention of Pulmonary TB transmission in Tulungagung Regency.

Table 11: The Effect of Officers Coaching with the Prevention of Pulmonary TB Transmission

\begin{tabular}{|c|c|c|c|c|c|c|c|}
\hline \multirow[t]{3}{*}{ Health workers coaching } & \multicolumn{6}{|c|}{$\begin{array}{l}\text { Pulmonary TB disease prevention behavior } \\
\text { towards the relatives }\end{array}$} & \multirow[t]{3}{*}{$\rho$ value } \\
\hline & \multicolumn{2}{|c|}{ Less } & \multicolumn{2}{|c|}{ Satisfactory } & \multicolumn{2}{|c|}{ Good } & \\
\hline & $\mathrm{N}$ & $\mathrm{F}$ & $\mathrm{N}$ & $\mathrm{F}$ & $\mathrm{N}$ & $\mathrm{F}$ & \\
\hline Less & 54 & 18,9 & 8 & 2,8 & 2 & 0,7 & $\rho=0,000$ \\
\hline Satisfactory & 86 & 30,2 & 30 & 10,5 & 23 & 8,1 & \\
\hline Good & 31 & 10,9 & 29 & 10,2 & 22 & 7,7 & \\
\hline
\end{tabular}




\section{MULTIVARIATE ANALYSIS}

\begin{tabular}{lcc}
\hline Variable & Wald & P \\
& & \\
& & \\
\hline Age & 0,000 & 0,998 \\
Gender & 4,808 & 0.028 \\
Education level & 1997 & 0.000 \\
Job field & 0,000 & 0.997 \\
Knowledge & 6.205 & 0.013 \\
Dwelling density & 14.211 & 0.000 \\
Ventilation broad & .001 & 0.234 \\
Window Area & .089 & 0.355 \\
Distance & 1.416 & 0.234 \\
PMO & 1.646 & 0.355 \\
Officers coaching & 4.316 & 0.038 \\
\hline
\end{tabular}

$\alpha=0,05$

Based on ordinal regression result, it was obtained five variables which were dominantly influence the prevention of Pulmonary TB transmission, namely health workers coaching, gender, knowledge, dwelling density and education level. 
Journal for Quality in Public Health

Vol. 1 No. 1 Januari 2018

\section{DISCUSSION}

Based on the research, there was an effect between respondents' gender with the prevention of Pulmonary TB transmission in Tulungagung Regency.

It was accordance with another research done by Erni Erawatiningsih which stated that there was no relationship between genders towards disobedience of treatment on Pulmonary TB patient in Puskesmas of West Dompu in 2009. Man received less treatment in preventing the reduction of Pulmonary TB due to their hard workload and smoking habit which facilitated the transmission occurrence.

Based on the research, there was an effect between respondents' age with the prevention of Pulmonary TB transmission in Tulungagung Regency. It was in accordance with the research done by Datulong conducted in Wori Mena village in 2015, asserted that there was a relationship between age with Pulmonary Tuberculosis cases. Hiswani (2009) stated that the exposure of TBC disease on people was influenced by several factors which were social and economic status, nutrition status, and age. Age can influence people to commit the prevention towards the transmission of Pulmonary TB due to the increasing age of person, it will increase their knowledge and awareness in doing the prevention as well in order to get a healthy life and be spared by any disease.

Based on the research, there was the effect between respondents' education level with the prevention of Pulmonary TB transmission in Tulungagung Regency. It was compliance with the research done by Fariz Muaz in 2004 in Serang which asserted that there was a meaningful relation between education and the patients of BTA positive Pulmonary TB. Based on the research done by Tony and Tobing which was conducted in North Tapanuli in 2009 was also stated that there was a meaningful effect between education with the potential of TB transmission. Education is one of factors which can influence the exposure of Pulmonary TB
p-ISSN: 2614-4913

e-ISSN: 2614-4921

disease from patients to their relatives, because a higher education of person will make people think more critical in responding certain situation in which will influence their sustainability life, especially for health. Thus, by a higher education, people will attempt to execute the best prevention effort in order to spare from any disease.

Based on research, there was an effect between respondents' job field with the prevention of Pulmonary TB transmission in Tulungagung Regency. It was in accordance with other research done by Fariz Muaz conducted in Serang City in 2014 which mentioned that there was a meaningful relation between job and the patients of BTA positive Pulmonary TB (Muaz, 2014). Nevertheless, based on the research done by Ahmad Hudan conducted in 2014 in Puskesmas of Pamulung Tangerang concluded that there was a meaningful relation between job field with the level of Pulmonary Tuberculosis medication adherence (Hudan, 2013). People's job field will influence family's income which had an impact towards the lack of nutrient intake, health care and lack of ability in selecting healthy dwelling so as to make a decrease of endurance and facilitate the occurrence of TBC disease.

Based on the research data, the highest number of having lack treatment on pulmonary TB prevention was housewife. It was happened because a housewife is a person who frequently has a direct contact with the patient, either physically nor non physically, and a housewife is a person who has the highest workload in the house so as to has less attention in their own cleanness and health, and a housewife is a person who has a long time to contact with the transmission source which were in the house.

From the result of the research, there was an effect between respondents' knowledge with the prevention of Pulmonary TB transmission in Tulungagung Regency. It was compliance with the research done by Fariz Muaz 


\section{Vol. 1 No. 1 Januari 2018}

conducted in Serang in 2014 that there was a meaningful relation between knowledge with the patients of BTA positive pulmonary TB (Muaz, 2013). The research which was done by Tony Lumban Tobing conducted in 2009 in North Tapanuli, there was an effect between knowledge with the potential of Pulmonary TB transmission. (Tobing, 2009). Based on the research done by Erni Erawatyningasih conducted in west Nusa Tenggara in 2009 stated there was an effect between knowledge and the disobedience treatment of Pulmonary TB patient and disobedience of taking medicine by patients (Erawatyningsih, 2009). People's knowledge will influence their health, so as to by a sufficient knowledge, it make those people attempted to behave a healthy life. Likewise TB patients, after knowing about their illness, they would know the purpose of medical treatment, transmission, prevention, and so on.

From the research results, there was no effect between dwelling density with the prevention of pulmonary tuberculosis transmission in Tulungagung regency. The results of this study were in line with research conducted by Jendra F.J Dotulong in 2015, there was no strong relationship between dwelling density with the incidence of Pulmonary TB disease in Wori Village, Wori District. (Dotulong, 2015). In a study conducted by Tony Lumban Tobing in 2009 said that there was a significant relationship between the dwelling density with potential pulmonary TB transmission, (Tobing, 2009). Difference results were obtained on ordinal regression test, which showed the effect of dwelling density in preventing pulmonary tuberculosis transmission to family members. This happened because all the independent variables were tested all at once. Dwelling density is one of the risk factors of TB. The transfer of disease, especially infectious diseases through the air will be easier and faster due to the dwelling density, if there were family
e-ISSN: 2614-4921

members who suffer from TB with BTA positive which got cough by chance. Bacteria of mycobacterium Tuberculosis will stay in the air for approximately 2 hours so as to have the possibility to transmit disease in members who have not been exposed to bacteria M.Tuberkulosis. (Datulong, 2015).

Dwelling density of a residence can be the transmission factor of a disease, because the more densely populated will facilitate the occurrence of spreading pulmonary Tuberculosis disease among family members with Pulmonary TB patients which living in one house resulting in the increasing of the incidence of Pulmonary TB.

From the research result there was no influence between ventilation area with the prevention of pulmonary tuberculosis transmission in Tulungagung regency. The result of this study was in accordance to the results of a study conducted by Erlin Fitria Dewi in 2016 in Magelang that said there was no relationship between the ventilation area with the incidence of Pulmonary TB. (Dewi, 2016). However, unlike the research conducted by Tony Lumban Tobing in 2009 in North Tapanuli District, there was a significant relationship between ventilation area and the potential of pulmonary tuberculosis transmission. (Tobing, 2009).

Eligible ventilation has a very important role in regulating air circulation, so the air inside the house remains fresh and maintains the oxygen balance required by each family member. Unqualified ventilation causes the air humidity to be higher that the tubercle microbe become resistant and do not easily die. This of course makes the risk of transmission of disease from patients to the family members who live at home to be higher.

From the results of research there was no influence between the window area with prevention of pulmonary tuberculosis transmission in Tulungagung regency. The results of this study was similar to the results of research conducted by Erlin 
Journal for Quality in Public Health

Vol. 1 No. 1 Januari 2018

Fitria Dewi in 2016 in Magelang which states there was no relationship between lighting with the incidence of Pulmonary TB. The results of research on the actions taken by the family in efforts to prevent transmission of Pulmonary TB to other family members in line with research conducted by Mery in 2010 which mentions sunlight can kill bacteria disease, virus and fungus, it is very useful for the treatment of TB disease. Bacteria in the air can be destroyed by the sun light in a short time. In contrast with a research conducted by Tony Lumban Tobing in 2009 in North Tapanuli District which states that there was a significant relationship between the window area with the potential of Pulmonary TB transmission. (Tobing, 2009).

The light is very important, because it can kill pathogenic bacteria at home, such as TBC bacilli. Therefore, a healthy home must have sufficient entrance of light. Obviously light entrance (window) of the extent of at least $15 \%$ to $20 \%$ of the floor area contained in the room of the house.

From the result of research indicated there was influence between distance of house with health facility in preventing the transmission of Pulmonary $\mathrm{TB}$ in Tulungagung regency.

This was in line with research which was conducted by Ahmad Hudan in 2013 in Pamulang Tanggerang stated that there was an influence distance to health facilities with an obidience for taking drugs anti - Pulmonary Tuberculosis, (Hudan, 2013). But unlike the research conducted by Erny Erawatyningsih in 2009 in West Nusa Tenggara that there was no relationship between the distance to health facilities with the compliance of treatment of Pulmonary TB patients. (Erawatyningsih, 2009).

House distance which close to the health facility in the study was not well utilized by the community to check themselves or seek information in terms of prevention of pulmonary TB transmission disease. This can happen because of the
p-ISSN: 2614-4913

e-ISSN: 2614-4921

lack of motivation from health workers to invite the general community and families of pulmonary TB patients, especially in terms of delivering information about pulmonary TB disease and prevention.

The reluctance of family members of pulmonary tuberculosis to visit the nearest health facility to get an explanation about pulmonary tuberculosis disease and its prevention can also be affected by the lack of leisure time due to the busyness of daily activities, the absence of transportation support and the limited cost to visit health facilities.

From the research result there was influence between the active role of family members as PMO with the prevention of pulmonary TB transmission in Tulungagung regency.

This was in line with research conducted by Tony Lumban Tobing in 2009 in Tapanuli which stated that there was a meaningful relationship between family support potential of pulmonary TB transmission. (Tobing, 2009). Whereas in a study conducted by Erni Erawatyningsih in 2009 in Nusa Tenggara said that there was no influence of PMO with nonadherence taking medication in patients with pulmonary tuberculosis (Erawatyningsih, 2009). Different data obtained from research conducted by Ahmad Hudan in 2013 in Pamulang Tanggerang, concluded that there was no influence of family support with adherence to taking anti- pulmonary Tuberkuosis medicine. (Hudan, 2013).

Although the variables used in the research were different, but the point was that family support as a supervisor taking medicine was very influential on the prevention of pulmonary TB transmission disease. The active role of family members as PMO was very needed by people with pulmonary tuberculosis, because of the supervision, it was expected that the patient will be obedient to take medicine and free from pulmonary TB disease so that the risk of transmission to other family member will decrease. 
PMO from family members improved patient compliance in taking the medicine of resistant microbe (immune) medicine. To achieve it, it was important to ensure that the patient swallowed all the medications given as directed by direct supervision by the PMO (Medication Treatment Observer, or often also called the Medication Swallowing Supervisor) in order to prevent the resistance. However, the family member must be given education first by health workers about the details of TB disease.

Based on the research showed that there was influence between the development of health officer with the prevention of pulmonary TB transmission in Tulungagung regency.

This was in line with research which was conducted by Tony Lumban Tobing in 2009 in Tapanuli, concluded that there was a meaningful relationship between coaching officers with the potential of pulmonary TB transmission. (Tobing, 2009). While in research conducted by Erni Erawatyningsih in year 2009 in Nusa Tenggara there was no influence of service quality of officer with disobedience to take medication in patient of Pulmonary TB (Erawatyningsih, 2009).

Guidance and counceling of health workers were needed in providing continuous knowledge to pulmonary TB patients and family members thus it was expected that patients and other family members were able to prevent the pulmonary TB transmission disease well so as to the incidence rate of pulmonary tuberculosis can be suppressed. Guidance and counceling of health workers were also indispensable in providing continuous motivation to pulmonary TB patients and their family members so that they were always willing with full awareness to prevent the pulmonary TB transmission disease for the health of surrounding environment in general and personal health particularly.

\section{CONCLUSION:}

In accordance with the background of the study and theobjectives as well as the results of the research that has been done on 285 respondents in preventing the transmission of pulmonary tuberculosis on patients' relatives in Tulungagung regency, it can be drawn conclusion as follows:

1. Predisposing Factors

From 285 respondents mostly 152 respondents of woman, aged between 36-45 years as much as 77 respondents (34.8\%). Senior High School was as many as 125 respondents $(43.8 \%)$, housewife was as much as 102 respondents $(36.1 \%)$ and have a good knowledge about pulmonary tuberculosis as much as 200 respondents $(70.3 \%)$.

2. Enabling Factor

From 285 respondents, most of them had dwelling density $\geq 2.5 \times 3 \mathrm{~m} 2 /$ person as much as 169 respondents $(59.3 \%)$, ventilation area $\leq 10 \%$ of floor area as much as 166 respondents $(58,3 \%)$, window $<15 \%-20 \%$ of the floor area as much as 169 respondents $(59.3 \%)$, and house distance to the health facility $<3 \mathrm{Km}$ as much as 167 respondents (48.6\%).

3. Reinforcing Factor

From 285 respondents, active well in PMO activities as much as 140 respondents (49.2\%) and get adequate guidance from health workers as much as 138 respondents $(48.4 \%)$.

4. Predisposing factors that affected in the prevention of pulmonary TB transmission disease in the family of the patient were gender, age, education level, type of work and knowledge of respondents.

5. Enabling factors that affected the dwelling density and distance of the house to health facilities with prevention of pulmonary tuberculosis transmission in families of patients in Tulungagung regency

6. Reinforcing factors that influenced the prevention of pulmonary tuberculosis 
transmission in patients' relatives in Tulungagung regency was the active role of family members as PMO and the development of health workers

7. That there was an influence between wald parameter test result on ordinal regression test explaining that gender variable, education level, knowledge, density of residence and coaching officer had a significant influence to preventive behavior toward pulmonary tuberculosis transmission disease in Tulungagung regency. In the other words $\mathrm{H} 0$ was rejected $(\alpha=0.05)$.

\section{SUGGESTION}

According to this research, it was found that gender, education level, knowledge, dwelling density and coaching officer had a significant influence on prevention behavior toward pulmonary tuberculosis transmission in Tulungagung regency. Therefore, there were some suggestions that can be submitted by researcher as follows:

1. The need of additional of other variables in further similar studies in order to know what factors can improve the prevention of pulmonary TB transmission disease in families of patients in Tulungagung regency.

2. The need of efforts to increase knowledge for the society through counseling, simulation and empowerment of PKK in routine arisan activities, posyandu with a theme of prevention of pulmonary TB transmission disease.

3. There is an increasing of health service and health officer development to Pulmonary TB patients and their family in effort to prevent Pulmonary TB transmission disease.

4. The health service shall improve the quality of pulmonary TB officers in carrying out the services and elucidation related to pulmonary $\mathrm{TB}$ disease.

\section{REFERENCES}

Astuti, S, 2013, Hubungan Tingkat
Pengetahuan dan Sikap Masyarakat
Terhadap Upaya Pencegahan penyakit
Tuberkulosis di RW 04 Kelurahan Lagowa
Jakarta Utara Tahun 2013ロSkripsi, S.Kep,
UIN Syarif Hidayatullah, Jakarta

Bimantara, J.G. 2016, Tuberkolosis di Indonesia Terbanyak Kedua di Dunia, Kompas, Maret 2016

Budiman dan riyanto, A. 2013, Kapita Selekta Kuesioner :Pengetahuan dan Sikap Dalam Penelitian Kesehatan, Salemba Medika, Jakarta, Indonesia

Datulong Jendra F.J, 2015, Hubungan Faktor Resiko Umur, Jenis Kelamin dan Kepadatan Hunian Dengan Kejadian Penyakit TB Paru Di Desa Wori Kecamatan Wori, Universitas Sam Ratulangi Menado, Indonesia

Derektoral Jendral pengendalian Penyakit dan Penyehatan Lingkungan 2015, Rencana Aksi Program Pengendalian Penyakitdan Penyehatan Lingkungan, Jakarta, Indonesia

Dinas Kesehatan Provinsi Jawa Timur, 2013, Profil Kesehatan Provinsi JawaTimur 2012, Surabaya, Indonesia

Dewi Erlin Fitri, 2016, Hubungan Faktor Lingkungan Rumah Dengan Kejadian TB Paru Di Kota Magelang,Universitas Diponegoro, Solo, Indonesia

Erawatyningsih, 2009, Faktor-Faktor yang Mempengaruhi Ketidakpatuhan Berobat pada Penderita TB Paru, Fakultas kedokteran UGM, Yogyakarta, Indonesia

Hastono P.S , 2016, Analisis Data Pada Bidang Penelitian, PT Raja Grafndo Persada, Jakarta, Indonesia

Hudan Akhmad, 2013, Faktor-Faktor Yang Mempengaruhi Kepatuhan Minum Obat Anti Tuberkulosis Pada Pasien Tuberkulosis Paru di Puskesmas Pamulang Kota Tanggerang Selatan Propinsi Banten Periode Januari 2013Januari 2013ロSkipsi, UIN Syarif Hidayatullah, Jakarta

Humaira, 2013, „, Faktor-faktor yang Berhubungan Dengan Perilaku Pasien Tuberkulosis Paru dalam Pencegahan Penularan di 
Journal for Quality in Public Health

Vol. 1 No. 1 Januari 2018

Puskesmas Tanggerang Selatan $\square$ Skripsi, S.Kep, UIN Syarif Hidayatullah, Jakarta

Irianto, K. 2014, Ilmu Kesehatan Masyarakat, Afabeta, Bandung, Indonesia

Jaji, 2010, Upaya Keluarga Dalam Pencegahan Penularan Tuberkulosis (TB) Paru ke Anggota Keluarga Lainnyadi Wilayah Kerja Puskesmas Sidorejo, http://oprintis.unsri.ac.id/2889/1/jurnal_Jaj i_PSik_FK_UNSRI_Jurnal_FKM.Pdf

Kementerian Kesehatan RI Direktorat Bina Upaya Kesehatan, 2012, Pedoman

Pencegahan dan Pengendalian Infeksi Tuberkulosis Di Fasilitas Pelayanan Kesehatan, Jakarta, Indonesia.

Kementerian Kesehatan RI Direktorat Jendral Pengendalian Penyakit dan penyehatan Lingkungan, 2014, Pedoman Nasional Pengendalian Tuerkulosis, Jakarta, Indonesia

Kuswiyanto (ed), 2015, Bakteriologi I Buku Ajar Analis Kesehatan, EGC, Jakarta, Indonesia

Lailatul, M.N, Rohmmah, S. danWicaksana, A.Y, 2015, Upaya Keluarga Untuk Mencegah Penularan Dalam Perawatan Anggota Keluarga TB Paru .Jurnal Keperawatan UMM 6(2) diakses 2 April 2017, http//portalgaruda,org

Muas Fariz, 2014, Faktor-faktor Yang Mempengaruhi Kejadian Tuberkulosis Paru Basil Tahan Asam Positif Di Puskesmas Wilayah Kecamatan Serang Kota Serang Tahun 2014, $\square$ Skripsi, UIN Syarif Hidayatullah, Jakarta

Notoatmodjo, $\mathrm{S}_{\mathrm{a}}$. 2011, Kesehatan Masyarakat Ilmu dan seni, Rineka Cipta, Jakarta, Indonesia Notoadmodjo, S. 2010, Metodelogi Penelitian Kesehatan, RinekaCipta, Jakarta, Indonesia

Notoadmodjo, $\mathrm{S}_{\mathrm{b}}$. 2010, Promosi Kesehatan Teori dan Aplikasi, Rineka Cipta, Jakarta, Indonesia

Nugroho, F.A dan Astuti,E.P, 2010, Hubungan Tingkat Pengetahuan dan Sikap Dengan Perilaku Pencegahan Penularan Tuberkulosis Paru Pada Keluarga, JurnalSTIKes RS Baptis, Volume 1, Edisi 1, 19-28
p-ISSN: 2614-4913

e-ISSN: 2614-4921

Sanjaya Yasin, 2014, Faktor-Faktor Yang Berhubungan Dengan Perilaku Kesehatan Kehamilan, Diaksespada 27 April 2017, http://www.sarjanaku.com/2013/04/faktorfaktor-yang-berhubungan-dengan.html

Siyoto S, Sari N, 2016, Aplikasi dan Teknik Survey Bidang Kesehatan, Literasi Media, Yogyakarta, Indonesia.

Siyoto S., Sodik A., 2015, Dasar Metodologi Penelitian, Literasi Media, Yogyakarta, Indonesia.

Susila dan Suyanto, 2014, Metode Penelitian Epidemologi Bidang Kedokteran dan Kesehatan, Bursa Ilmu, Yogyakarta, Indonesia 